\title{
JĘZYKOZNAWSTWO POLONISTYCZNE NA UNIWERSYTECIE JAGIELLOŃSKIM DAWNIEJ I DZIŚ (W 10 ROCZNICĘ POWSTANIA WYDZIAŁU POLONISTYKI UJ) ${ }^{1}$
}

Słowa klucze: historia językoznawstwa, językoznawstwo polonistyczne, Uniwersytet Jagielloński, Wydział Polonistyki UJ

Keywords: history of linguistics, Polish linguistics, Jagiellonian University, Jagiellonian University's Faculty of Polish Studies

W niniejszym artykule przedstawię, poczynając od 2. połowy XIX w., ogólny zarys historii, a następnie teraźniejszości językoznawstwa polonistycznego na Uniwersytecie Jagiellońskim. Podstawą materiałową są tu dawniejsze opracowania traktujące o przeszłości slawistyki i polonistyki (Lehr-Spławiński, Urbańczyk 1964; Taszycki 1964; Karaś 1974; Urbańczyk 1974, 1993), artykuły poświęcone poszczególnym językoznawcom (Złota Ksiegga) oraz informacje, jakie otrzymałem z istniejących na Wydziale Polonistyki obecnie katedr językoznawczych.

1 Artykuł jest rozszerzoną wersją referatu wygłoszonego na nadzwyczajnym posiedzeniu Rady Wydziału Polonistyki UJ 29 IV 2016 r. Serdecznie dziękuję prof. M. Skarżyńskiemu za cenne uwagi, które w znaczący sposób wpłynęły na kształt niniejszego tekstu. 


\section{Katedry i ludzie}

1.1. Początków językoznawstwa polonistycznego można szukać już w działalności Karola Mecherzyńskiego, który w latach 1854-1864 jako wykładowca Katedry Historii Języka i Literatury Polskiej zajmował się (choć czynił to bez przekonania) także historią polszczyzny. Po nim należy wymienić Henryka Sucheckiego, profesora na Katedrze Porównawczej Lingwistyki Słowiańskiej. W roku akademickim 1865/1866 podjął on wykłady z gramatyki języka polskiego. Jako pierwszy z wykładających na UJ filologów zajął się także językiem ludowym (wykład „Mowa pieśni ludu polskiego praktycznie z wykazaniem różnic dialektycznych") oraz tym, co dziś nazywamy kulturą języka (wykłady i ćwiczenia, m.in. „O błędach w polszczyźnie potocznych...”, „Rozmowy naukowe o wątpliwych i spornych kwestiach w zakresie polszczyzny piśmiennej...”, „Poprawa błędów, osobliwie germanizmów zakorzenionych w dzisiejszej polszczyźnie literackiej”).

Po śmierci Sucheckiego w 1872 r. przez cztery lata szukano następcy na jego miejsce. Brano pod uwagę Lucjana Malinowskiego z Warszawy i bliżej nieznanego obecnie J. Radwańskiego z Krakowa. O opinię o kandydatach poproszono Franza Miklosicha; ten uznał, że żaden z kandydatów nie jest wystarczająco przygotowany. W 1874 r. zwrócono się do Jana Baudouina de Courtenay, który nie mógł przyjąć propozycji ze względu na konieczność odpracowania stypendium rządu rosyjskiego. Myślano też o Władysławie Nehringu i Józefie Przyborowskim (byłym profesorze Szkoły Głównej Warszawskiej). W 1875 r. Miklosicha poproszono ponownie o opinię o L. Malinowskim oraz o Emilu Kałużniackim. Pod wpływem opinii wiedeńskiego slawisty Wydział Filozoficzny UJ postanowił zatrudnić Kałużniackiego, ale Ministerstwo Oświaty skierowało go na katedrę slawistyki uniwersytetu w Czerniowcach. W ten sposób w 1876 r. profesorem na Katedrze Filologii Porównawczej Słowiańskiej (a wkrótce: Katedrze Filologii Słowiańskiej) został Malinowski.

Malinowski jest uznawany za twórcę polskiej dialektologii i onomastyki, a w pewnym stopniu również historii języka. W odróżnieniu od Mecherzyńskiego i Sucheckiego umiał on skupić wokół siebie grupę studentów i zachęcić ich do badań językowych. Byli to: Jan Biela, Jan Bystroń, Gustaw Blatt, Wojciech Grzegorzewicz, Stanisław Dobrzycki, Jan Hanusz, Władysław Kosiński, Roman Zawiliński i Kazimierz Nitsch.

W 1893 r. zaproszono do Krakowa uwolnionego już od rosyjskich zobowiązań Baudouina de Courtenay. Początkowo objął on Katedrę Językoznawstwa Porównawczego i Sanskrytu, a po śmierci Malinowskiego Katedrę Filologii Słowiańskiej, co prawda tylko na rok. Baudouin wniósł zupełnie nowe i oryginalne podejście do językoznawstwa i języka, a choć wykładał krótko, to miał wpływ na kształtowanie się poglądów naukowych Jana Rozwadowskiego, a w pewnym stopniu także K. Nitscha. Ze znanych na ogół powodów politycznych ministerstwo nie odnowiło w $1899 \mathrm{r}$. kontraktu Baudouina. 
W Katedrze Filologii Słowiańskiej nastąpił stan prowizorium. Stanowisko profesora tymczasowo objął Rozwadowski. Rada Wydziału Filozoficznego zobligowała go do znalezienia kandydata stricte polonistycznego. Początkowo myślano o Aleksandrze Brücknerze, który odmówił, wymawiając się złym stanem zdrowia. Później zwrócono się do Wiktora Porzezińskiego, profesora na Uniwersytecie Moskiewskim. Nie był on polonistą, lecz indoeuropeistą, a głównie bałtystą. Także on odmówił. Dopiero trzeci językoznawca - docent Uniwersytetu Petersburskiego Jan Łoś zgodził się i w 1902 r. objął katedrę slawistyki.

1.2. W 1920 r. utworzono odrębną Katedrę Języka Polskiego i powierzono ją Łosiowi, natomiast na Katedrę Filologii Słowiańskiej powołano K. Nitscha, w latach 1916-1920 profesora filologii słowiańskiej na uniwersytecie we Lwowie. Po śmierci Łosia w 1928 r. Katedrę Języka Polskiego objął właśnie Nitsch².

Nitsch kierował katedrą do przejścia na emeryturę w 1939 r. Na swego następcę rekomendował Witolda Taszyckiego (wówczas we Lwowie), a ponieważ ten się wycofał, Nitsch polecił Zenona Klemensiewicza.

1.3. W początkach lat 2o. Nitsch zaproponował zreformowanie slawistyki (dotąd było to właściwie samo językoznawstwo) i utworzenie zespołu katedr obejmującego także katedry literaturoznawcze i nauk pomocniczych (na wzór Seminarium Słowiańskiego Uniwersytetu Karola w Pradze). Myśl tę częściowo zrealizowano w 1925 r. Powstało wówczas Studium Słowiańskie składające się początkowo z katedr: Językoznawstwa Słowiańskiego (Nitsch), Języków Wschodniosłowiańskich (Iwan Ziłyński), Literatury Rosyjskiej (Wacław Lednicki), Literatury Ukraińskiej (Bohdan Łepki), Etnografii Słowiańskiej (Kazimierz Moszyński) i Historii Sztuki Narodów Słowiańskich (Vojeslav Molè). Później włączono Katedrę Filologii Południowosłowiańskiej (Mieczysław Małecki), a po wojnie Katedrę Języka Polskiego (Klemensiewicz). Kierownictwo Studium Słowiańskiego sprawowali kolejno: Nitsch (1925-1937), Molè (1937-1939), Małecki (1945-1946) i Lehr-Spławiński (1946-1950).

1.4. Rozwadowski, Nitsch i Łoś stworzyli, jeszcze przed I wojną, prawdziwą szkołę naukową. To właśnie uczniowie „krakowskiej trójcy” po 1918 r., gdy potrzebne były kadry naukowe dla innych ośrodków uniwersyteckich, czy to „starych” (Lwów) czy właśnie tworzonych (Poznań, Wilno), objęli na nich katedry.

Druga wojna światowa zahamowała badania, ale nauczanie trwało - działał bowiem podziemny Uniwersytet Jagielloński. Pracowali w nim (po zwolnieniu z obozu koncentracyjnego) K. Nitsch, M. Małecki i Stanisław Urbańczyk oraz Z. Klemensiewicz i Franciszek Sławski.

1.5. W 1945 r. powstał Wydział Humanistyczny UJ, w którego strukturze znalazła się też kierowana przez Z. Klemensiewicza Katedra Języka Polskiego. W 1947 r. utworzono dla Taszyckiego Katedrę Onomastyki Słowiańskiej, którą dwa lata później przekształcono w Katedrę Filologii Staropolskiej.

2 Na katedrę slawistyczną powołano po Nitschu Tadeusza Lehra-Spławińskiego. 
W 1950 r. rozwiązano (oficjalnie w trosce o jednolitość metodyczną i tematyczną) Studium Słowiańskie, a na jego miejsce powołano Instytut Językoznawstwa. Za tymi niekorzystnymi i, jak się okazało, nie ostatnimi zmianami stały czynniki polityczne. Rok później Wydział Humanistyczny zmienił się w Wydział Filologiczny.

W 1952 r. powstała zbiorowa Katedra Języka Polskiego, obejmująca Zakład Języka Polskiego i Zakład Filologii Staropolskiej (wcześniej katedry). Kierownikami zakładów pozostali Klemensiewicz i Taszycki. Ten drugi był ponadto kierownikiem całości (do przejścia na emeryturę w 1968 r.).

1 X 1962 r. zakłady przemianowano: Zakład Języka Polskiego na Zakład Współczesnego Języka Polskiego (pod kierownictwem Mieczysława Karasia), a Zakład Filologii Staropolskiej na Zakład Historii Języka (Taszycki).

Instytut Językoznawstwa UJ składał się ostatecznie z trzech dużych katedr: Językoznawstwa Ogólnego (Jerzy Kuryłowicz), Języka Polskiego (Taszycki) i Filologii Słowiańskiej (Lehr-Spławiński).

Po marcu 1968 r. na polskich uczelniach zaczęto przeprowadzać zmiany nie tylko kadrowe, ale i strukturalne, w których rezultacie 1 VI 1970 r. Katedra Języka Polskiego i Katedra Historii Literatury Polskiej połączyły się w Instytut Filologii Polskiej. Językoznawcza część nowej struktury składała się z Zakładu Gramatyki Synchronicznej i Dialektologii Języka Polskiego (M. Karaś) i Zakładu Gramatyki Diachronicznej (Ewa Ostrowska). Po śmierci Karasia i Ostrowskiej w 1977 r. nastąpiła reorganizacja, powstały: Zakład Historii Języka i Dialektologii (Bogusław Dunaj) i Zakład Współczesnego Języka Polskiego (Zofia Kurzowa). W 1996 r. zakłady zostały przekształcone $\mathrm{w}$ katedry. $\mathrm{Z}$ czasem naturalnym biegiem rzeczy zmieniło się też ich kierownictwo. Następczynią Z. Kurzowej została w 2001 r. Janina Labocha, a B. Dunaja - w 2010 r. Renata Przybylska.

1.6. 1 V 2005 r. z Katedry Historii Języka i Dialektologii wydzielono Katedrę Lingwistyki Kulturowej i Socjolingwistyki (Halina Kurek), a z Katedry Współczesnego Języka Polskiego Zakład (później Katedrę) Teorii Komunikacji (Jolanta Antas). Do tych czterech katedr po utworzeniu Wydziału Polonistyki dołączyła Katedra Języka Polskiego jako Obcego (Władysław Miodunka, od 2015 r. Iwona Janowska). Wcześniej (od 1980 r.) był to Zakład Językoznawstwa Stosowanego do Nauczania Języka Polskiego jako Obcego w Instytucie Badań Polonijnych UJ. To wszystko działo się już na nowo powołanym Wydziale Polonistyki. 


\section{Dyscypliny i ludzie}

2.1. Dialektologia. Krakowskie językoznawstwo zaczęło się od dialektologii. Pierwszą naukową polską pracą dialektologiczną, autorstwa L. Malinowskiego, były Beiträge zur slavischen Dialectologie. Ueber die Oppelnsche Mundart (1873) ${ }^{3}$. Najwybitniejszy uczeń Malinowskiego, K. Nitsch, prowadził badania terenowe, które przyniosły opisy większości polskich dialektów, m.in. w pracach Mowa ludu polskiego (1911) i Dialekty języka polskiego (1915), a także opracował koncepcję Słownika gwar polskich. Dialektologią zajmował się również (choć w nieporównanie mniejszym stopniu niż Nitsch) Łoś, który zredagował trzy tomy Słownika gwar polskich Jana Karłowicza.

Do pierwszego pokolenia uczniów Nitscha należeli m.in. S. Urbańczyk (1953), Zdzisław Stieber (badacz dialektów pogranicza - wschodniej Słowacji, Łemkowszczyzny i Łużyc), W. Taszycki (1934) i M. Małecki. Ostatni z nich wspólnie z Nitschem opracował Atlas językowy polskiego Podkarpacia (Nitsch, Małecki 1934), uznawany za jedną z najważniejszych prac dialektologicznych okresu międzywojennego.

Do drugiego pokolenia uczniów można liczyć M. Karasia i Alfreda Zarębę. Pierwszy z nich podejmował zagadnienia ogólniejsze, miał przy tym umiejętność organizowania prac zespołowych. Był redaktorem Małego atlasu gwar polskich oraz Słownika gwar polskich PAN. Z kolei Zaręba skupił się na dialektologii śląskiej (Atlas językowy Śląska (1969-1996) i Słownik Starych Siołkowic w powiecie opolskim (1960)). Wspólnie badali gwary Polskiej Orawy.

Uczniami Karasia byli także m.in. Józef Bubak i B. Dunaj. Wokół Dunaja powstała szkoła dialektologiczna, do której należą Józef Kąś i Kazimierz Sikora. Pierwszy zajmuje się przede wszystkim leksykografią podtatrzańską. Opublikował Słownik gwary orawskiej (2003) oraz trzy pierwsze tomy Ilustrowanego leksykonu gwary $i$ kultury podhalańskiej (2015-2016). Słowniki te stanowią wzór opracowań nowego typu, łączących opis językowy z opisem etnograficznym. K. Sikora zainteresowania skupił na wiejskiej etykiecie językowej (2010).

Najmłodsze pokolenie dialektologów to: Tomasz Kurdyła, Agata Kwaśnicka-Janowicz, Anna Piechnik i Maciej Rak.

T. Kurdyłę interesuje głównie słowotwórstwo gwarowe i jego odmienność w stosunku do słowotwórstwa języka literackiego (2011). A. Kwaśnicka-Janowicz jest autorką książki o wpływach leksykalnych polsko-ukraińskich w zakresie obrzędowości weselnej (2005). A. Piechnik zajmuje się gwarowym słownictwem ekspresywnym (2009), a M. Rak frazeologią gwarową (2005, 2007; Rak, Sikora 2016) i kulturemami (2015). Prace Kwaśnickiej-Janowicz, Piechnik i Raka należą zarówno do dialektologii, jak i do etnolingwistyki.

3 W tej i dalszej części artykułu z braku miejsca przywołuje się w związku z wymienianymi postaciami tylko niektóre prace. 
Bardzo ważna dla badań dialektologicznych była inicjatywa Janusza Strutyńskiego - Bibliografia dialektologii polskiej (1981-1990). Obecnie pracę tę kontynuuje H. Kurek.

2.2. Socjolingwistyka. Zajmują się nią H. Kurek i Mirosława Sagan-Bielawa. Kurek (1990, 1995, 2003) przedmiotem badań uczyniła zmiany, jakie w ostatnim czterdziestoleciu dokonują się na polskiej wsi. Odrębną pracę poświęciła polszczyźnie mówionej inteligencji (2008). Z kolei M. Sagan-Bielawa zagadnienia socjolingwistyczne ujmuje w perspektywie historycznej (2014). Autorami prac z zakresu socjolingwistyki są także: Dunaj, Kąś (1994) i Sikora.

2.3. Historia języka. Początki historii języka jako dyscypliny są związane z działalnością L. Malinowskiego. Był on inicjatorem powstania Stownika staropolskiego, jednak brak programu (nie określono ram czasowych słownika ani kanonu źródeł) sprawił, że materiały zebrane do tego opracowania zostały po śmierci pomysłodawcy uznane za bezużyteczne i zniszczone. Nową instrukcję przygotował Baudouin de Courtenay, a wdrożył ją Łoś. Wydawanie słownika ukończono dopiero w $2002 \mathrm{r}$. (SStp).

Po Malinowskim historią polszczyzny zajmowali się Rozwadowski (w pewnym zakresie) i Łoś. Ich działalność szła dwutorowo - wydawali zabytki języka polskiego, tym samym przygotowując bazę materiałową, oraz opracowywali poszczególne działy polszczyzny do Encyklopedii polskiej AU (t. 2-3: Język polski i jego historia). Rozwadowski (1915) skupił się na fonetyce historycznej, a Łoś na składni. Należy dodać, że od nośne językowe artykuły z Encyklopedii polskiej złożyły się (po dokonaniu koniecznych zmian) na pierwszą akademicką gramatykę języka polskiego (GJP 1923).

W różnym stopniu historią języka polskiego zajmowało się kolejne pokolenie badaczy: Lehr-Spławiński (1946), Klemensiewicz (1961-1972), Tadeusz Milewski (1927), Taszycki (1933) i Ostrowska (1967). Szczególne miejsce zajmują tu Historia języka polskiego Klemensiewicza (1961-1972) oraz Gramatyka historyczna języka polskiego Klemensiewicza, Lehra-Spławińskiego i Urbańczyka (1955).

Do następnego pokolenia historyków języka należą: B. Dunaj (1975), Aleksander Zajda (1970, 1979, 1990, 2001; Urban, Zajda 2004), Jan Godyń (2009) i Zofia Cygal-Krupa (1979). Obecnie mimo kilku pojedynczych prac (Mycawka 2012, Przęczek-Kisielak 2012) trzeba zauważyć, że badania historycznojęzykowe faktycznie zamarły - w tym zakresie tradycja szkoły krakowskiej została przerwana.

2.4. Onomastyka. Największy wkład w rozwój badań onomastycznych wnieśli: Rozwadowski, Taszycki, a w późniejszym czasie Karaś, Bubak i Strutyński. Rozwój badań onomastycznych, prowadzonych intensywnie już w okresie międzywojennym (np. Rozwadowski 1948), nastąpił głównie z inicjatywy Taszyckiego, który położył na tym polu największe zasługi (założył czasopismo „Onomastica”, był redaktorem Stownika staropolskich nazw osobowych (1965-1987) oraz autorem prac z zakresu antroponimii $(1924,1926))$. 
Toponimią zajmował się Karaś $(1955,1968)$, antroponimią terenów południowej Małopolski Bubak (1970-1971, 1992), a Strutyński urbozoonimią (1996). Obecnie badania onomastyczne na Wydziale Polonistyki zostały zarzucone.

2.5. Historia polskiego językoznawstwa. Jest przedmiotem zainteresowania Mirosława Skarżyńskiego, który przygotował trzy tomy źródeł (Skarżyński, Smoczyńska 2007; Czelakowska, Skarżyński 2011; Skarżyński 2016), edycje wspomnień Henryka Ułaszyna (2010) i dawnych prac (Baudouin de Courtenay 2007; Ułaszyn 2009), a także książki o gramatykach polskich XIX i XX w. (2001) i o kształtowaniu się metodologii słowotwórstwa opisowego (1999).

2.6. Językoznawstwo opisowe. W tym zakresie na czoło wysuwają się osiągnięcia Klemensiewicza, badacza składni $(1937,1967-1969)$ i autora gramatyki (1939). Znacznie później składnia polszczyzny była też przedmiotem zainteresowania J. Labochy (1995) i Kingi Tutak (Labocha, Tutak 2005).

W drugiej połowie lat 7o. i na początku lat 8o. językoznawcy z IFP UJ podjęli nowe kierunki badań. Wyznacznikiem tych zmian stało się przezwyciężenie ograniczeń związanych $z$ dominacją metody filologicznej i przesunięcie punktu ciężkości z problematyki historycznojęzykowej na zagadnienia współczesnego języka mówionego.

Z inicjatywy M. Karasia powstał Słownik wymowy polskiej (Karaś, Madejowa 1977), a także plan badań polszczyzny mówionej Krakowa. Nagła śmierć pomysłodawcy nie przekreśliła tych planów. Kontynuował je B. Dunaj i jego zespół (Aleksy Awdiejew, Krystyna Data, Halina Kurek, Józef Kąś, Jadwiga Kowalikowa, Janina Labocha, Kazimierz Ożóg, później dołączyli Renata Przybylska, Ewa Horwath, Kazimierz Sikora i in.).

W tym samym czasie Z. Kurzowa realizowała ze swoimi uczniami (Wacław Cockiewicz (1988; Cockiewicz, Śliwiński 1989), Bronisława Ligara, Zofia Kubiszyn-Mędrala, Monika Szpiczakowska, Władysław Śliwiński (Cockiewicz, Śliwiński 1989), Justyna Winiarska (2001)) badania nad językiem telewizji polskiej. Efektem prac obydwu zespołów były między innymi tomy zbiorowe (Dunaj 1981, 1984; Dunaj, Ożóg 1991; Kurzowa, Śliwiński 1994).

Zmianami w leksyce i językiem polityki zajmowała się Danuta Wesołowska (1978), a W. Miodunka (1980) rozwinął teorię pól językowych. W ostatnich zaś latach nurt kognitywny reprezentuje R. Przybylska (2002, 2006; Borowicz, Hobot, Przybylska 2010).

Słowotwórstwem opisowym w odniesieniu do materiału polskiego, współczesnego i dawniejszego, a także słowiańskiego oraz metodologią opisu zajmowała się Z. Kurzowa (1970, 1976), później badał je M. Skarżyński (1999, 2000, 2004a, b). Obecnie słowotwórstwo współczesnej polszczyzny oraz paronimia są przedmiotem zainteresowania Donaty Ochmann (2004).

Agnieszka Sieradzka-Mruk (2003, 2016) prowadzi badania teolingwistyczne, Barbara Batko-Tokarz (2008) zajmuje się dyskursem politycznym oraz metaleksykografią, a Patrycja Pałka (2009) dyskursem publicznym. 
Słownictwo tematyczne języka polskiego zostało opracowane przez Z. Cygal-Krupę $(1986,1990)$.

Szczególne miejsce zajmuje leksykografia. W 1996 r. ukazał się Słownik wspótczesnego języka polskiego pod redakcją B. Dunaja (1996). Trzy lata później wyszedł Ilustrowany słownik podstawowy jezzyka polskiego... Z. Kurzowej (1999).

Ze słowników specjalistycznych należy wymienić: Słownik ortograficzny i prawidła pisowni polskiej Stanisława Jodłowskiego i W. Taszyckiego (1951); Słownik synonimów polskich Z. Kurzowej, Z. Kubiszyn-Mędrali, M. Skarżyńskiego, J. Winiarskiej (Kurzowa 1998); Mały słownik słowotwórczy języka polskiego dla cudzoziemców M. Skarżyńskiego (1989); Słownik semantyczno-syntaktyczny przymiotników polskich W. Śliwińskiego (1993).

2.7. Tekstologia. Tekst, jego struktura, spójność i funkcjonowanie w procesie komunikacji są domeną J. Labochy (1990, 2008) i K. Tutak (2003, 2013). Z kolei zagadnienia stylu i języka artystycznego na tle typów i gatunków tekstów bada W. Śliwiński (2000, 2012, 2014).

2.8. Język pisarzy i utworów. Wybrane aspekty języka Pana Tadeusza opisała M. Szpiczakowska (2001), językiem Zygmunta Krasińskiego zajęła się B. Ligara (1987), a Stanisława Wyspiańskiego - W. Śliwiński (ostatnio grant: Słownictwo dyferencjalne w dramatach Stanisława Wyspiańskiego - studia leksykologiczno-leksykograficzne).

2.9. Lingwistyka komunikacyjna. Jest rozwijana w Katedrze Teorii Komunikacji w czterech tematach badawczych:

1) Werbalne i niewerbalne składniki aktu komunikacyjnego: J. Antas (2013), Aneta Załazińska (2000, 2006, 2016).

2) Strategia, rytuał, gra jako językowe sposoby uczestniczenia w życiu społecznym: J. Antas, A. Załazińska, Beata Drabik (2004, 2010), Anna Chudzik (2002) i Izabela Kraśnicka-Wilk.

3) Międzykulturowe badania porównawcze skryptów zachowań komunikacyjnych: J. Antas, B. Drabik, A. Chudzik i I. Kraśnicka-Wilk.

4) Sposoby konceptualizacji języka dokonywane na gruncie językoznawstwa kognitywnego: J. Winiarska.

Do semantyki i pragmatyki językowej należą dwie wcześniejsze książki J. Antas (1991, 1999).

2.10. Kontakty polszczyzny $\mathrm{z}$ innymi językami. $\mathrm{W}$ tym zakresie szczególne miejsce zajmują prace Z. Kurzowej poświęcone polszczyźnie Lwowa (1983) i Wilna (1993). Sytuację języka polskiego na Śląsku Cieszyńskim opisywała J. Labocha (1997). Bilingwizm pisarzy był przedmiotem badań B. Ligary (1987).

Wielojęzyczność i bilingwizm polsko-obcy są podejmowane przez pracowników Katedry Języka Polskiego jako Obcego: W. Miodunkę (np. 2003), Roberta Dębskiego i Przemysława Gębala.

2.11. Glottodydaktyka. Glottodydaktyka jest domeną Katedry Języka Polskiego jako Obcego. Kręgi badawcze, które są tu rozwijane, to: 
1. Językoznawstwo stosowane do nauczania języka polskiego jako obcego.

2. Metodyka i dydaktyka języka polskiego jako obcego.

3. Glottodydaktyka polonistyczna.

4. Glottodydaktyka porównawcza.

5. Kontakty językowe polsko-obce w krajach osiedlenia Polonii.

Do glottodydaktyki należy też praca B. Ligary (Ligara, Szupelak 2012).

Katedra Języka Polskiego jako Obcego publikuje w utworzonej w 2011 r. serii „Biblioteka LingVariów. Glottodydaktyka”, w której dotychczas wydano 11 tomów. Osobną serię stanowią podręczniki do nauczania języka polskiego jako obcego.

\section{Podsumowanie}

Nawet tak skrótowy przegląd przeszłości polonistycznego językoznawstwa na Uniwersytecie Jagiellońskim pozwala zauważyć wyraźnie rysujące się najogólniejsze linie ewolucyjne: a) od polonistyki „slawistycznej” ku polonistyce „autonomicznej” i „wyemancypowanej” (z oczywistą szkodą dla językoznawstwa4), b) od dominującej diachronii do dominującej synchronii oraz c) (w ostatnich 30-40 latach) od opisów systemowych do badań tekstowych i komunikacji. Pierwsza linia ewolucyjna była ogólnopolska, dwie pozostałe także nie są charakterystyczne dla środowiska krakowskiego, ale wiążą się z wymianą paradygmatów w lingwistyce w ogóle.

W tym procesie zgubiono, niestety, diachronię, a jedna czy druga pojedyncza praca $\mathrm{z}$ tego zakresu w ostatnich latach nie daje powodu do tego, by dobrze rokować na przyszłość. Zwłaszcza że od dłuższego już czasu wśród najmłodszego pokolenia potencjalnych badaczy (doktorantów) nie widać zainteresowania językoznawstwem historycznym. Tak więc o krakowskiej szkole diachronicznej raczej myśleć na bliższą przyszłość nie można.

Jeśli pozwolić sobie teraz na spojrzenie „czysto synchroniczne” na sytuację językoznawstwa na Wydziale Polonistyki UJ, to - opierając się na danych bibliograficznych z ostatnich dziesięciu, piętnastu lat - można zauważyć ogromną różnorodność podejmowanych wątków badawczych. $Z$ jednej strony jest to zjawisko pozytywne, $\mathrm{z}$ drugiej jest ono wynikiem rozejścia się dróg naukowych pracowników katedr językoznawczych, co niekoniecznie sprzyja podejmowaniu prac zespołowych. Na tym tle wyjątkami są Katedra Teorii Komunikacji, konsekwentnie od początku realizująca dokładnie określone zakresy badawcze, i Katedra Lingwistyki Kulturowej i So-

4 A to dlatego, że owa emancypacja przyniosła w programach studiów wyeliminowanie takich przedmiotów jak wstęp do filologii słowiańskiej, podstawy (choćby) gramatyki porównawczej języków słowiańskich, co w oczywisty sposób zawęża perspektywę spojrzenia na język polski. Jest to zresztą zjawisko ogólnopolskie, którego źródła tkwią, jak się wydaje, w dawniejszych decyzjach ministerialnych. 
cjolingwistyki. Są to najmłodsze katedry językoznawcze, które zostały w pewnym momencie zorganizowane na zasadzie: profesor - jego uczniowie. „Stare” Katedry siłą rzeczy muszą pozostać zróżnicowane w swych składach osobowych, choćby dlatego, że są (w uproszczeniu) nie dwupokoleniowe, jak owe dwie wymienione, ale „wielopokoleniowe”. Reszta należy do przyszłości.

\section{Literatura}

Antas J., 1991, O mechanizmach negowania. Wybrane semantyczne i pragmatyczne aspekty negacji, Kraków.

Antas J., 1999, O kłamstwie i kłamaniu. Studium semantyczno-pragmatyczne, Kraków.

Antas J., 2013, Semantyczność ciała. Gesty jako znaki myśli, Łódź.

Batko-TokARz B., 2008, Perswazja $w$ dyskursie sejmowym, Kraków.

Baudouin de Courtenay J., 2007, Miejcie odwage myślenia... Wybór pism publicystycznych $z$ lat 1898-1927. Opracował, wstępem i przypisami opatrzył M. Skarżyński, „Biblioteka Klasyki Polskiej Myśli Politycznej”, t. XVIII, Kraków.

Borowicz S., Новот J., Przybylska R., 2010, Stara rebeliantka. Studia nad semantyka obrazu, Kraków.

BubaK J., 1970-1971, Nazwiska ludności dawnego powiatu nowotarskiego, cz. 1, Warszawa Kraków, cz. 2, Wrocław.

BuBAK J., 1992, Słownik nazw osobowych i elementów identyfikacyjnych Sądecczyzny XV-XVII w. (imiona, nazwiska, przezwiska), cz. 1-2, Kraków.

Chudzik A., 2002, Mowne zachowania magiczne w ujęciu pragmatyczno-kognitywnym, Kraków.

Cockiewicz W., 1988, Komentarz transmisji sportowej w telewizji (charakterystyka składniowa). Studium z zakresu składni języka mówionego, Kraków.

Cockiewicz W., ŚLIWIŃsKi W., 1989, Właściwości składniowo-stylistyczne języka telewizji polskiej (na materiale list frekwencyjnych), Warszawa - Kraków.

Cygal-Krupa Z., 1979, Szesnastowieczne edycje „Dictionarii Ioannis Murmellii variarum rerum...", cz. 1: Uwagi ogólne, ortografia, fonetyka, cechy dialektyczne, Kraków.

Cygal-Krupa Z., 1986, Słownictwo tematyczne języka polskiego. Zbiór wyrazów w układzie rangowym, alfabetycznym i tematycznym, Kraków.

Cygal-Krupa Z., 1990, Podstawowe słownictwo tematyczne jezzyka polskiego (na wybranych przykładach), Kraków.

Czelakowska A., Skarżyński M., 2011, Materiały do dziejów polskiego językoznawstwa. Listy Jana Niecisława Baudouina de Courtenay, Jana Łosia, Kazimierza Nitscha, Jana Michała Rozwadowskiego, Henryka Ułaszyna, „Biblioteka LingVariów”, t. 8, Kraków.

DrABIK B., 2004, Komplement $i$ komplementowanie jako akt mowy i komunikacyjna strategia, Kraków.

DRABIK B., 2010, Językowe rytuały tworzenia więzi interpersonalnej, Kraków.

DunaJ B., 1975, Język polski najstarszej doby piśmiennej (XII-XIII w.), „Zeszyty Naukowe UJ” „Prace Językoznawcze” nr 45.

Dunaj B. (red.), 1981, Studia nad polszczyzna mówioną Krakowa 1, „Zeszyty Naukowe UJ” „Prace Językoznawcze” nr 70. 
Dunaj B. (red.), 1984, Studia nad polszczyzną mówioną Krakowa 2, „Zeszyty Naukowe UJ” „Prace Językoznawcze” nr 79.

Dunaj B. (red.), 1996, Słownik współczesnego języka polskiego, Warszawa.

Dunaj B., Ożóg K. (red.), 1991, Studia nad polszczyzną mówioną Krakowa 3, „Zeszyty Naukowe UJ” „Prace Językoznawcze” nr 107.

GJP 1923: T. Benni, J. Łoś, K. Nitsch, J. Rozwadowski, H. Ułaszyn, Gramatyka języka polskiego, Kraków 1923.

Godyń J., 2009, Studia historycznojęzykowe, edytorskie, kulturalnojęzykowe, „Biblioteka LingVariów", t. 4, Kraków.

JoDŁOWSKI S., TASZYCKI W., 1951, Słownik ortograficzny i prawidła pisowni polskiej, Wrocław.

Karaś M., 1955, Nazwy miejscowe typu „Podgóra”, „Zalas” w języku polskim i w innych językach słowiańskich, Wrocław.

Karaś M., 1968, Toponimia Wysp Elafickich na Adriatyku, Wrocław.

KARAś M., 1974, Językoznawstwo w krakowskim środowisku naukowym, „Zeszyty Naukowe UJ” "Prace Historyczne” nr 47, s. 191-222.

Karaś M., Madejowa M. (red.), 1977, Słownik wymowy polskiej, Warszawa - Kraków.

KĄś J., 1994, Interferencja leksykalna słownictwa gwarowego i ogólnopolskiego (na przykładzie gwar orawskich), Kraków.

KĄś J., 2003, Słownik gwary orawskiej, Kraków.

KĄś J., 2015-2016, Ilustrowany leksykon gwary i kultury podhalańskiej, Bukowina Tatrzańska - Nowy Sącz.

Klemensiewicz Z., 1937, Składnia współczesnej polszczyzny kulturalnej, Kraków.

Klemensiewicz Z., 1939, Gramatyka współczesnej polszczyzny kulturalnej w zarysie, Lwów - Warszawa.

Klemensiewicz Z., 1961-1972, Historia języka polskiego, cZ. 1: 1961, cZ. 2: 1965, cZ. 3: 1972, Warszawa.

Klemensiewicz Z., 1967-1969, Studia syntaktyczne, t. 1: 1967, t. 2: 1969, Wrocław.

Klemensiewicz Z., Lehr-SpŁawiński T., UrbańCZyk S., 1955, Gramatyka historyczna języka polskiego, Warszawa.

KuRDYŁA T., 2011, Funkcje formantów rzeczownikowych w polszczyźnie ludowej (na przykładzie trzech wsi podkarpackich), „Biblioteka LingVariów”, t. 12, Kraków.

KuREK H., 1990, Metodologia socjolingwistycznego badania fonetyki języka mówionego środowisk wiejskich (na przykładzie kilku wsi Beskidu Niskiego), Kraków.

KureK H., 1995, Przemiany językowe wsi regionu krośnieńskiego. Studium socjolingwistyczne, Kraków.

Kurek H., 2003, Przemiany leksyki gwarowej na Podkarpaciu, Kraków.

Kurek H., 2008, Polszczyzna mówiona inteligencji, Kraków.

Kurzowa Z., 1970, Polskie rzeczowniki męskie na -o na tle słowiańskim, Wrocław.

Kurzowa Z., 1976, Złożenia imienne we współczesnym języku polskim, Warszawa - Kraków.

Kurzowa Z., 1983, Polszczyzna Lwowa i kresów południowo-wschodnich do 1939 roku, Warszawa - Kraków.

Kurzowa Z., 1993, Język polski Wileńszczyzny i kresów północno-wschodnich XVI-XX w., Warszawa - Kraków.

Kurzowa Z. (red.), 1998, eadem, Z. Kubiszyn-Mędrala, M. Skarżyński, J. Winiarska, Słownik synonimów polskich, Warszawa.

Kurzowa Z., 1999, Ilustrowany słownik podstawowy języka polskiego wraz z indeksem pojęciowym wyrazów i ich znaczeń, Kraków. 
Kurzowa Z., ŚLIwiński W. (red.), 1994, Współczesna polszczyzna mówiona w odmianie opracowanej (oficjalnej), Kraków.

KwaśniCKa-JanOwiCZ A., 2005, Polsko-ukraińskie związki leksykalne w zakresie obrzędowości weselnej w gwarach okolic Przemyśla, Kraków.

Lавосна J., 1990, Opowiadania ludowe ze Śląska Cieszyńskiego w Czechosłowacji w świetle pragmalingwistyki tekstu, Kraków.

LAвосна J., 1995, Gramatyka polska, cz. III: Składnia, Kraków.

Laвосна J., 1997, Polsko-czeskie pogranicze na Śląsku Cieszyńskim. Zagadnienia językowe, Kraków.

LAвосна J., 2008, Tekst, wypowiedź, dyskurs w procesie komunikacji językowej, Kraków.

Laвосна J., Tutak K., 2005, Podstawy analizy składniowej wypowiedzeń, Kraków.

Lehr-SpŁaWiński T., 1946, O pochodzeniu i praojczyźnie Słowian, Poznań.

Lehr-Sp£awiński T., UrbańCZy K S., 1964, Przegląd dziejów słowianoznawstwa w Uniwersytecie Jagiellońskim, [w:] W. Taszycki, A. Zaręba (red.), Wydział Filologiczny Uniwersytetu Jagiellońskiego. Historia katedr, Kraków, s. 163-214.

LigARA B., 1987, Galicyzmy leksykalne w listach Zygmunta Krasińskiego na tle wpływów francuskich w polszczyźnie XIX w. Studium bilingwizmu polsko-francuskiego, "Zeszyty Naukowe UJ” „Prace Językoznawcze” nr 86.

Ligara B., Szupelak W., 2012, Lingwistyka i glottodydaktyka języków specjalistycznych. Na przykładzie języka biznesu. Podejście porównawcze, „Biblioteka LingVariów. Glottodydaktyka", t. 3, Kraków.

Malinowski L., 1873, Beiträge zur slavischen Dialektologie. Ueber die Oppelnsche Mundart, Leipzig.

MaŁecki M., Nitsch K., 1934, Atlas językowy polskiego Podkarpacia, cz. 1-2, Kraków.

MAŁY ATLAS GWAR POLSKICH, t. 1-2, red. K. Nitsch, t. 3-13, red. M. Karaś, Wrocław 1957-1970.

Milewski T., 1927, Dwie bulle wrocławskie z lat 1155 i 1245 , „Prace Filologiczne” XI, s. 439-461.

Miodunka W., 1980, Teoria pól językowych: społeczne i indywidualne ich uwarunkowania, „Zeszyty Naukowe UJ” „Prace Językoznawcze” nr 67.

Miodunka W., 2003, Bilingwizm polsko-portugalski w Brazylii. W stronę lingwistyki humanistycznej, Kraków.

MrCAWKa M., 2012, Język polski XIV wieku. Wybrane zagadnienia, Kraków.

Nitsch K., 1911, Mowa ludu polskiego, Kraków.

Niтsch K., 1915, Dialekty języka polskiego, [w:] Encyklopedia polska, t. 3, dział 3, cz. 2: H. Ułaszyn i in. (oprac.), Język polski i jego historia, z uwzględnieniem innych języków na ziemiach polskich, Kraków, s. 238-343.

Ochmann D., 2004, Nowe wyrazy złożone o podstawie zdezintegrowanej w języku polskim, Kraków.

Ostrowska E., 1967, O artyzmie polskich średniowiecznych zabytków językowych (Bogurodzica, Kazania świętokrzyskie, „Posłuchajcie bracia miła”), „Zeszyty Naukowe UJ” „Prace Językoznawcze" nr 20.

PAŁKA P., 2009, Strategie dyskursywne w rozmowie handlowej, Katowice.

Piechnik A., 2009, Wizerunek kobiety i mężczyzny w językowym obrazie świata ludności wiejskiej (na przykładzie gminy Zakliczyn nad Dunajcem), Kraków.

PrZĘCZEK-Kisielak S., 2012, Właściwości fonetyczne małopolskich rot sądowych, Kraków.

Przybylska R., 2002, Polisemia przyimków polskich w świetle semantyki kognitywnej, Kraków. 
PRZYBYLSKA R., 2006, Schematy wyobrażeniowe a semantyka polskich prefiksów czasownikowych do-, od-, prze-, roz-, u-, Kraków.

RAK M., 2005, Słownik frazeologiczny gwary Dębna w Górach Świętokrzyskich, Kraków.

RAK M., 2007, Językowo-kulturowy obraz zwierząt utrwalony w animalistycznej frazeologii gwar Gór Świętokrzyskich i Podtatrza (na tle porównawczym), Kraków.

RAK M., 2015, Kulturemy podhalańskie, „Biblioteka LingVariów”, t. 19, Kraków.

RAK M., SikORA K. (red.), 2016, Słowiańska frazeologia gwarowa, „Biblioteka LingVariów”, t. 23, Kraków.

RozWADOWSKi J., 1915, Historyczna fonetyka, czyli głosownia języka polskiego, [w:] Encyklopedia polska, t. 2, dział 3, cz. 1: J. Łoś i in. (oprac.), Język polski i jego historia, z uwzględnieniem innych języków na ziemiach polskich, Kraków, s. 288-422.

Rozwadowski J., 1948, Studia nad nazwami wód słowiańskich. Dzieło pośmiertne, Kraków.

Sagan-Bielawa M., 2014, Dziedzictwo pozaborowe. Społeczna świadomość językowa Polaków w Drugiej Rzeczypospolitej, „Biblioteka LingVariów”, t. 18, Kraków.

SŁOWNIK GWAR POLSKICH, red. M. Karaś (Źródła, t. 1), J. Reichan (t. 2-9, z. 2), S. Urbańczyk (t. 2-5), J. Okoniowa (t. 6-9, z. 2), B. Grabka (t. 7-9, z. 2), R. Kucharzyk (t. 9, z. 2), t. 1-3, Wrocław - Warszawa - Kraków 1977-1991, t. 4-9, z. 2, Kraków 1992-2015.

SierAdZKA-Mruk A., 2003, Odbiorca jako czynnik kształtujący wypowiedź (na przykładzie kazań dla dzieci), Kraków.

SIERADZKA-Mruk A., 2016, „Radość i nadzieja, smutek i trwoga” w nabożeństwie drogi krzyżowej. Wybrane aspekty ewolucji dyskursu religijnego $w$ XX wieku na przykładzie leksyki dotyczącej uczuć, „Biblioteka LingVariów”, t. 20, Kraków.

SikorA K., 2010, Grzeczność językowa wsi, cz. I: System adresatywny, Kraków.

SKARŻyŃsKi M., 1989, Mały słownik słowotwórczy języka polskiego dla cudzoziemców, Kraków.

SKARŻyński M., 1999, Powstanie i rozwój polskiego słowotwórstwa opisowego, Kraków.

SKARŻYŃsKi M., 2000, Liczebniki w słowotwórstwie współczesnej polszczyzny (studium gniazd słowotwórczych), Kraków.

SKARŻyŃsKi M. (red. i współaut.), 2004a, Słownik gniazd słowotwórczych współczesnego języka ogólnopolskiego, t. 3: Gniazda odczasownikowe, Kraków.

SKARŻYŃsKi M., 2004b, Słownik gniazd słowotwórczych współczesnego języka ogólnopolskiego, t. 4: Gniazda motywowane przez liczebniki, przysłówki, zaimki, przyimki, modulanty, onomatopeje, wykrzykniki, Kraków.

SKARŻYŃsKi M., 2011, W kręgu gramatyk polskich XIX i XX w., Kraków.

SKARŻyŃski M. (wyb., przekł. i oprac.), 2016, Materiały do dziejów polskiego językoznawstwa, II: Jan Baudouin de Courtenay, Teksty mniej znane, „Biblioteka LingVariów”, t. 21, Kraków.

SkARŻyński M., Smoczyńska M. (oprac.), 2007, Listy Jana Baudouina de Courtenay do Henryka Ułaszyna z lat 1898-1927, „Biblioteka LingVariów”, t. 1, Kraków.

SSTP: S. Urbańczyk (red.), Słownik staropolski, t. I-XI, Kraków 1953-2002.

StrutyŃski J. (red.), 1981-1990, Bibliografia dialektologii polskiej, t. 1: 1981, t. 2: 1986, t. 3: 1990, Kraków.

STRUtyŃski J., 1996, Urbozoonimia polska, Kraków.

SzPiczakowska M., 2001, Fonetyczne i fleksyjne cechy języka „Pana Tadeusza” Adama Mickiewicza na tle normy językowej XIX wieku, Kraków.

ŚLIWIŃsKI W., 1993, Słownik semantyczno-syntaktyczny przymiotników polskich, Kraków. 
ŚLIwIŃsKi W., 200o, Poetyckie konstrukcje nominalne w dziejach polskiego wiersza. Kategorie i subkategorie połaczeniowe, Kraków.

ŚLIWIŃsKi W. (red.), 2012, Język - styl - tekst w teorii i praktyce badawczej, Kraków.

ŚLIwiŃski W., 2014, Produktywność syntaktyczna leksemów w poetyckich konstrukcjach nominalnych od XVI do XX wieku, Kraków.

TAszYcki W., 1924, Polskie nazwy osobowe, Kraków.

TAszycki W., 1926, Najdawniejsze polskie imiona osobowe, Kraków.

TASZYCKi W., 1933, Nasza mowa ojczysta, Lwów.

TAsZyCKi W., 1934, Gwary ludu polskiego, Lwów.

TAszycki W., 1964, Historia Katedry Języka Polskiego w Uniwersytecie Jagiellońskim, [w:] idem, A. Zaręba (red.), Wydziat Filologiczny Uniwersytetu Jagiellońskiego. Historia Katedr, Kraków, s. 145-162.

TAszycki W. (red.), 1965-1987, Słownik staropolskich nazw osobowych, t. 1-7, Wrocław Warszawa - Kraków.

TutaK K., 2003, Leksykalne nieczasownikowe wykładniki modalności epistemicznej w autobiografiach, Kraków.

TutAK K., 2013, O dedykacjach $w$ drukach polskich XVI i XVII wieku (grafia i interpunkcja), „Biblioteka LingVariów”, t. 16, Kraków.

UŁaszyn H., 2009, Studia onomastyczne i socjolingwistyczne, Wstęp i dobór tekstów B. Walczak i M. Skarżyński, Poznań.

UŁAsZYN H., 2010, Z Kopiowatej na katedry uniwersyteckie. Wspomnienia, Z rękopisu opracował M. Skarżyński, „Biblioteka LingVariów”, t. 9, Kraków.

URBAN W., ZAJDA A. (oprac.), 2004, 1543. Zapisy polskojęzyczne w księgach sądów szlacheckich województwa krakowskiego, Kraków.

URBAŃCZY K S., 1953, Zarys dialektologii polskiej, Warszawa.

URBAŃCZyK S., 1974, Katedra Filologii Słowiańskiej Uniwersytetu Jagiellońskiego, „Zeszyty Naukowe UJ” „Prace Historyczne” nr 47, s. 223-236.

URBAŃCZY к S., 1993, Dwieście lat polskiego językoznawstwa (1751-1950), Kraków.

WesoŁowska D., 1978, Neosemantyzmy wspótczesnego języka polskiego, Kraków.

WiniarsKa J., 2001, Operatory metatekstowe $w$ dialogu telewizyjnym, Kraków.

ZajDA A., 1970, Nazwy urzędników staropolskich (do 1600 r.), „Zeszyty Naukowe UJ” „Prace Językoznawcze" nr 31.

ZAJDA A., 1979, Nazwy staropolskich powinności feudalnych danin i opłat (do 16oo r.), „Zeszyty Naukowe UJ” „Prace Językoznawcze” nr 60.

ZajDA A., 1990, Staropolska terminologia prawnicza (do 1500 r.), Kraków.

ZAJDA A., 2001, Studia z historii polskiego słownictwa prawniczego i frazeologii, Kraków.

ZAŁAZIŃsKA A., 2000, Schematy myśli wyrażane w gestach. Gesty metaforyczne obrazujace abstrakcyjne relacje i zasoby podmiotu mówiącego, Kraków.

ZAŁAZIŃsKa A., 2006, Niewerbalna struktura dialogu. W poszukiwaniu polskich wzorów narracyjnych i interakcyjnych zachowań komunikacyjnych, Kraków.

ZAŁAZIŃsKA A., 2016, Obraz, słowo, gest, Kraków.

ZARĘBA A., 1960, Słownik Starych Siołkowic w powiecie opolskim, Kraków.

ZARęBA A., 1969-1996, Atlas językowy Śląska, t. 1-8, Kraków.

Z£OTA KSIĘGA: J. Michalik, W. Walecki (red.), Uniwersytet Jagielloński. Złota Księga Wydziału Filologicznego, Kraków 2000. 


\section{Polish linguistics at the Jagiellonian University then and now (on the tenth anniversary of the creation of the Faculty of Polish Studies) Summary}

The paper presents a synthesis of the history and achievements of Polish linguistics cultivated at the Jagiellonian University since the second half of the $19^{\text {th }}$ century till this day. The beginnings are the first lectures which discussed the Polish language, followed by the creation of chairs, then the institute, and finally a separate Faculty of Polish Studies. The author interweaves the institutional and personal threads, and indicates the most important figures of old professors whose works were central to the development of Polish linguistics and its various fields. 